\title{
Adenoviral overproduction of interleukin-1 receptor antagonist increases beta cell replication and mass in syngeneically transplanted islets, and improves metabolic outcome
}

\author{
N. Téllez • M. Montolio • E. Estil·les $\cdot$ J. Escoriza • \\ J. Soler $\cdot$ E. Montanya
}

Received: 31 August 2006 / Accepted: 18 October 2006/ Published online: 13 January 2007

(C) Springer-Verlag 2007

\begin{abstract}
Aims/hypothesis Interleukin-1 receptor antagonist (IL1RN, also known as IL1RA) is a naturally occurring inhibitor of IL-1 action and its overproduction protects pancreatic islets from the deleterious effects of IL- $1 \beta$ on beta cell replication, apoptosis and function. The aim of this study was to determine whether viral gene transfer of the Illrn gene into rat islets ex vivo had a beneficial effect on the outcome of the graft.

Materials and methods Streptozotocin-diabetic Lewis rats were syngeneically transplanted with 500 or 800 Ad-Illrn-
\end{abstract}

Electronic supplementary material Supplementary material is available in the online version of this article at http://dx.doi.org/ $10.1007 / \mathrm{s} 00125-006-0548-1$ and is accessible to authorised users.

J. Soler $\cdot$ E. Montanya

Endocrine Unit, University Hospital Bellvitge,

L'Hospitalet de Llobregat,

Barcelona, Spain

N. Téllez $\cdot$ M. Montolio $\cdot$ E. Estil·les $\cdot J$. Escoriza $\cdot$ J. Soler $\cdot$

E. Montanya

Laboratory of Diabetes and Experimental Endocrinology,

Department of Clinical Sciences, University of Barcelona,

L'Hospitalet de Llobregat,

Barcelona, Spain

N. Téllez $\cdot$ M. Montolio $\cdot$ E. Estil les $\cdot J$. Escoriza $\cdot J$. Soler $\cdot$

E. Montanya

Biomedical Research Institute Bellvitge (IDIBELL),

L'Hospitalet de Llobregat,

Barcelona, Spain

E. Montanya $(\triangle)$

Endocrine Unit (13-2), Hospital Universitari de Bellvitge,

Feixa Llarga, s/n, 08907 L'Hospitalet de Llobregat,

Barcelona, Spain

e-mail: montanya@ub.edu infected or uninfected islets. Islet grafts were collected on day 3,10 or 28 after transplantation and beta cell apoptosis, replication, size and mass were determined.

Results Animals transplanted with 500 islets remained hyperglycaemic throughout the follow-up, as expected. Beta cell replication increased in the Ad-Illrn group on days 3, 10 and 28 after transplantation compared with normal pancreas. In uninfected islets, by contrast, beta cell replication was increased only on day 10 . Beta cell apoptosis was increased in all transplanted groups; it was $25 \%$ lower in the Ad-Illrn than in uninfected groups, but differences were not statistically significant. The initially transplanted beta cell mass was reduced on day 3, increasing subsequently in Ad-Illrn grafts, but not in uninfected grafts. When 800 islets were transplanted, all animals grafted with Ad-IlIrn-infected islets, but only $40 \%$ of those transplanted with uninfected islets, achieved normoglycaemia 14 days after transplantation.

Conclusions/interpretation Overproduction of IL1RN increased beta cell replication and mass of islet grafts and reduced the beta cell number required to achieve normoglycaemia.

Keywords Beta cell apoptosis · Beta cell mass .

Beta cell proliferation - Diabetes - Interleukin 1 beta . Interleukin 1 receptor antagonist . Islet transplantation . Pancreatic beta cell

\begin{tabular}{|c|c|}
\hline \multicolumn{2}{|c|}{ Abbreviations } \\
\hline Ad & adenovirus \\
\hline Ad-GFP & $\begin{array}{l}\text { adenovirus encoding for green fluorescent } \\
\text { protein }\end{array}$ \\
\hline Ad-Illrn & $\begin{array}{l}\text { adenovirus encoding for interleukin } 1 \text { receptor } \\
\text { antagonist }\end{array}$ \\
\hline
\end{tabular}




$\begin{array}{ll}\text { BrdU } & \text { 5-bromo-2'deoxyuridine } \\ \text { GFP } & \text { green fluorescent protein } \\ \text { IL1RN } & \text { interleukin 1 receptor antagonist } \\ \text { STZ } & \text { streptozotocin } \\ \text { TUNEL } & \text { terminal deoxynucleotidyl transferase biotin- } \\ & \text { dUTP nick end labelling }\end{array}$

\section{Introduction}

In the initial days after transplantation islets are particularly vulnerable [1], and more than half of the islet tissue is lost due to increased beta cell apoptosis and necrosis [2]. This initial beta cell death occurs before immunological rejection or recurrence of autoimmunity, is found in syngeneic, allogeneic and xenogeneic transplants, increases the beta cell mass needed to achieve normoglycaemia after transplantation, and may contribute to the long-term failure of the graft [3].

Many factors play a role in early beta cell damage and death after transplantation, including islet injury during isolation $[4,5]$, technical problems in the transplantation process [6], inadequate mass of islet tissue [7], hypoxia [8], exposure to the recipient hyperglycaemia [9], absence of survival factors present in the non-endocrine pancreas [10], or disruption of islet cellular connections to extracellular matrix [11]. In addition, non-specific inflammation at the grafted site, involving the expression of pro-inflammatory cytokines, is considered to play a role in early graft failure $[4,5,12,13]$. We have identified increased production of IL-1 $\beta$ in syngeneically transplanted islet grafts, thereby confirming the presence of an inflammatory process in early islet transplantation even in most favourable conditions for islet survival [14, 15]. Considering the well established cytotoxicity of IL-1 $\beta[16,17]$, we have hypothesised that IL-1 $\beta$ contributes to the damage of islet cells occurring in the initial days after transplantation.

Interleukin-1 receptor antagonist protein (IL1RN, also known as IL-1Ra) is a naturally occurring inhibitor of IL-1 action that binds to the type 1 IL-1 receptor, but does not initiate IL-1 signal transduction [18, 19]. IL1RN overproduction prevented the deleterious effects of IL-1 $\beta$ on beta cell function and apoptosis in cultured human islets [20]. In vivo, IL1RN administration prevented low-dose streptozotocin (STZ)-induced diabetes [21], and protected transplanted islets from allogeneic rejection [22] and autoimmune attack [23]. However, the potential effects of IL1RN on the initial non-specific beta cell damage after transplantation have not been determined.

We recently reported that IL1RN overproduction protected cultured islets from IL-1 $\beta$-induced reduction in beta cell replication, and also found increased beta cell replica- tion in a small number of islet grafts overproducing IL1RN [15]. These results lead us to hypothesise that IL1RN could block the non-specific inflammation mediated by IL- $1 \beta$ and the ensuing beta cell damage and death in recently transplanted islets. In this study we used a syngeneic islet transplantation model to test this hypothesis. We found that the overproduction of IL1RN has a beneficial effect on transplanted beta cell death, replication and mass, and on the metabolic outcome of the graft.

\section{Materials and methods}

Animals Animal experimental procedures were reviewed and approved by the Ethical Committee of the University of Barcelona. Male inbred LEW/SsNHsd rats (Harlan, Horst, the Netherlands) ( $8-10$ weeks old) were used as donors and recipients of transplantation. The recipients were made diabetic by a single intraperitoneal injection of STZ (Sigma Immunochemicals, St Louis, MO, USA), $60 \mathrm{mg} / \mathrm{kg}$ body weight. Diabetes was confirmed by the presence of hyperglycaemia, polyuria and no weight gain. Only rats with a blood glucose $>20 \mathrm{mmol} / 1$ on a minimum of two consecutive measurements were transplanted. Blood glucose was determined between 9 and $11 \mathrm{~h}$ in non-fasting conditions. Blood was obtained from the snipped tail and glucose was measured with a portable meter.

Experimental groups STZ-diabetic rats were randomly transplanted with 500 islets infected with adenovirus (Ad) encoding for IL1RN (Ad-IlIrn) or with 500 uninfected syngeneic islets. Transplantation of 500 islets provides a clearly insufficient beta cell mass to restore normoglycaemia in this model, and the animals were expected to remain hyperglycaemic after transplantation [24]. Since glucose is known to modify beta cell replication, apoptosis and mass, we used this model to ensure that Ad-Illrn-infected and uninfected islets would be exposed to the same level of hyperglycaemia after transplantation. Since adenoviral infection has been associated with cytopathic effects, control animals were transplanted with uninfected islets that were expected to provide a better outcome than islets infected with control adenovirus. Thus, Ad-Illrn-infected islets were compared against the best control islets. Grafts were removed on days $3(n=12), 10(n=12)$ and $28(n=12)$ after transplantation (six groups, $n=6$ for each experimental group).

To determine the effects of IL1RN overproduction on the metabolic outcome of the graft, two additional groups of STZ-diabetic rats were randomly transplanted with 800 islets infected with Ad-Illrn $(n=5)$ or 800 uninfected $(n=5)$ islets, a borderline beta cell mass that can restore normoglycaemia in some but not all STZ-diabetic rats 
[24]. Thus, this model was used to determine whether IL1RN overproduction could accelerate or increase the achievement of normoglycaemia after transplantation. The grafts were removed on day 28 after transplantation. After graft removal blood glucose was determined to assess the recurrence of hyperglycaemia. A group of control nontransplanted rats $(n=6)$ had their blood glucose and body weight determined weekly.

Islet isolation and gene transfer Islets were isolated by collagenase (Collagenase P; Boehringer Mannheim Biochemicals, Mannheim, Germany) digestion of the pancreas and hand-picked under a stereomicroscope two or three times, until a population of pure islets was obtained [25]. Groups of 200 islets were infected with Ad-Illrn or Ad encoding for green fluorescent protein (GFP; Ad-GFP) at a plaque-forming unit of $6.25 \times 10^{6}$ as previously described [15]. After infection, islets were incubated overnight in non-tissue culture treated plastic ware at $37^{\circ} \mathrm{C}$ in serumcontaining medium at $11.1 \mathrm{mmol} / \mathrm{l}$ of glucose. Uninfected islets had the same treatment as infected islets, but in the absence of adenovirus.

Islet transplantation and graft harvesting After overnight incubation, Ad-Illrn-infected and uninfected islets were counted into groups of 500 or 800 islets and transplanted under the left kidney capsule of the recipients [25]. To remove the graft, the kidney capsule surrounding the graft was incised and removed together with the graft. The grafts were immediately immersed in $4 \%$ paraformaldehyde-PBS, fixed overnight and, after removal of any excess paraformaldehyde by capillary action, weighed [25].

Efficiency of infection Since IL1RN can be naturally produced by islet cells [26] and by non-infected cells, the efficiency of infection was quantified in Ad-GFP-infected islets. At $24 \mathrm{~h}$ after infection, islets were dispersed into single cells and analysed by flow cytometry, as previously described [15].

IL1RN production was determined by immunohistochemistry in islets before and after transplantation. Sections were incubated overnight at $4{ }^{\circ} \mathrm{C}$ with a goat anti-human IL1RN antibody (final dilution 1:20) (R\&D Systems, Minneapolis, MN, USA). Visualisation was performed with LSAB+ System-HRP (DakoCytomation, Carpinteria, CA, USA).

Ad-GFP-infected islet grafts that were removed 3 days after transplantation were used to establish whether beta cells colocalised with GFP in transplanted islets. Sections were immunostained with a guinea pig anti-swine insulin antibody (dilution 1:250; DakoCytomation) and detection was performed with a secondary anti-rabbit Alexa Fluor 546-conjugated antibody (1:200; Molecular Probes, Leiden, the Netherlands). Preparations were analysed for colocali- sation by spectral confocal microscopy and images were processed with Leica Confocal Software, version 2.5 (Leica Microsystems Heidelberg, Mannheim, Germany).

CD68 immunohistochemistry To identify the presence of macrophages, a well-known source of IL-1 $\beta$, we stained CD68-producing cells (monocyte/macrophage lineage marker) in islet grafts. The sections were incubated overnight at $4{ }^{\circ} \mathrm{C}$ with mouse anti-rat CD68 antibody (final dilution 1:100; Serotec, Oxford, UK), and visualisation was performed by Envision+ System-HRP (DakoCytomation).

Beta cell apoptosis Sections were double-stained by immunoperoxidase for apoptotic nuclei using the terminal deoxynucleotidyl transferase biotin-dUTP nick end labelling (TUNEL) technique (In Situ Cell Death Detection Kit, ApopTag; Intergene, Oxford, UK) and by alkaline phosphatase for the endocrine non-beta cells of the islets [2]. A cocktail of antibodies (DakoCytomation) including rabbit anti-swine glucagon (final dilution 1:1,000), rabbit antihuman somatostatin (final dilution 1:1,000) and rabbit antihuman pancreatic polypeptide (final dilution 1:500) was used [2]. We stained the endocrine non-beta cells instead of beta cells because the high glucose concentrations used in most of the experimental conditions are associated with beta cell degranulation and may result in weak insulin staining. We have previously shown the validity of staining the endocrine non-beta cells to determine beta cell apoptosis [2]. When assessing apoptotic nuclei we excluded necrotic regions. Beta cell apoptosis was expressed as percentage of TUNEL-positive beta cells. A minimum of 1,200 beta cells were counted per graft.

Beta cell apoptosis was also determined in six pancreases from normal Lewis rats $(8-10$ weeks old).

Beta cell replication Rats were injected with the thymidine analogue 5-bromo-2'deoxyuridine (BrdU; Sigma), $100 \mathrm{mg} / \mathrm{kg}$ body weight i.p., $6 \mathrm{~h}$ before removing the graft. Sections were double stained with immunoperoxidase for BrdU using a cell proliferation kit (Amersham, Amersham, UK) with a modified protocol [2]; for endocrine non-beta cells of the islets the cocktail of antibodies described above was used. To validate this measurement, beta cell replication was also determined in sections stained for beta cells with an anti-insulin antibody. A rabbit anti-human insulin antibody (1:50) (Santa Cruz Biotechnology, Santa Cruz, CA, USA) was used.

Beta cell replication was also measured in the pancreases of six normal Lewis rats (8-10 weeks old) injected with BrdU 6 h before pancreas excision. Beta cell replication in islet grafts and in control pancreas was expressed as percentage of BrdU-positive beta cells, and at least 1,200 beta cells were counted per sample. 

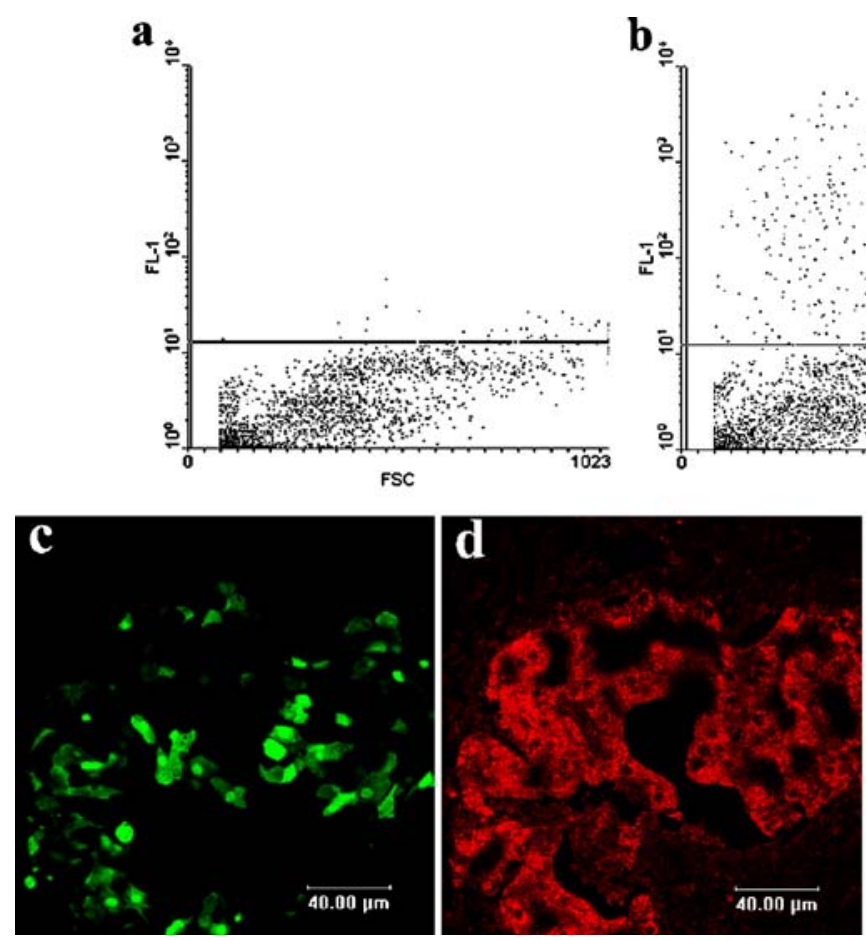

Fig. 1 Efficiency of adenovirus islet infection analysed by flow cytometry and immunocytochemistry. Dispersed islet cells of uninfected islets (a) and Ad-GFP islets (b) were analysed by flow cytometry for GFP production $24 \mathrm{~h}$ after infection (FL-1 detects green fluorescence). The micrographs (c-e) show an islet graft on day 3 after transplantation of Ad-GFP-transduced islets visualised by

Individual beta cell area The mean cross-sectional area of individual beta cells, a measure of beta cell size, was determined using image-analytical software (AnalySIS 3.0; Soft Imaging System, Münster, Germany) [2]. The individual beta cell area on the day of transplantation was determined in sections from the six groups of 500 isolated islets that were used to measure the initially transplanted beta cell mass. For both grafts and isolated islets, the perimeter of the beta cell tissue on a random field was carefully traced on the computer's monitor to exclude any other tissue, and the total beta cell area and beta cell nuclei $(302 \pm 22$ nuclei per sample) in that field were determined. To calculate the area of the individual beta cells, the total beta cell area in the field was divided by the number of beta cell nuclei.

Beta cell mass Beta cell mass measured by point-counting morphometry as previously described [27]. Beta cell mass was obtained by multiplying the weight of the graft by the relative beta cell volume.

The beta cell mass of islets at the time of transplantation was determined in six groups of 500 islets isolated on different days. Islets were pelleted, and then fixed and weighed as described for islet grafts. The beta cell mass was obtained by multiplying the weight of the islets by the percentage of beta cell volume, determined with image-
FSC
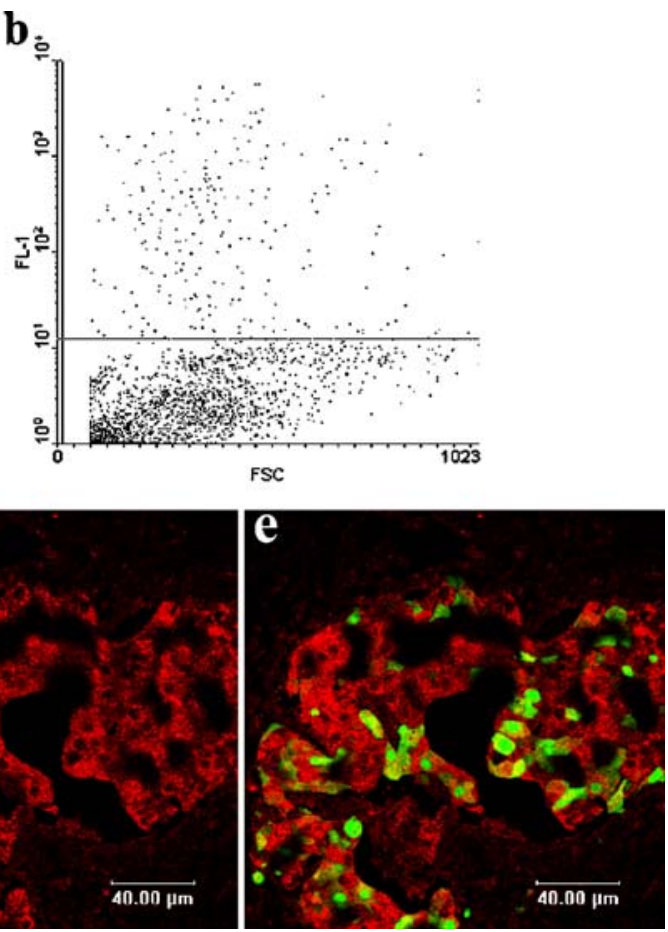

confocal microscopy, confirming coproduction of GFP (c) and insulin (d) by some cells (e) in transplanted islets. Note that the merge of GFP (green) and insulin (red) does not result in orange due to the high intensity of the GFP signal, compared with that of insulin. FSC, forward scatter cytometry

analytical software (AnalySIS 3.0; Soft Imaging System) on sections of the islet pellets.

Statistical analysis Results were expressed as means \pm SE. Statistics were performed using SPSS 14.0S for Windows, and differences between means were evaluated by ANOVA. The Fisher's protected least significant difference method

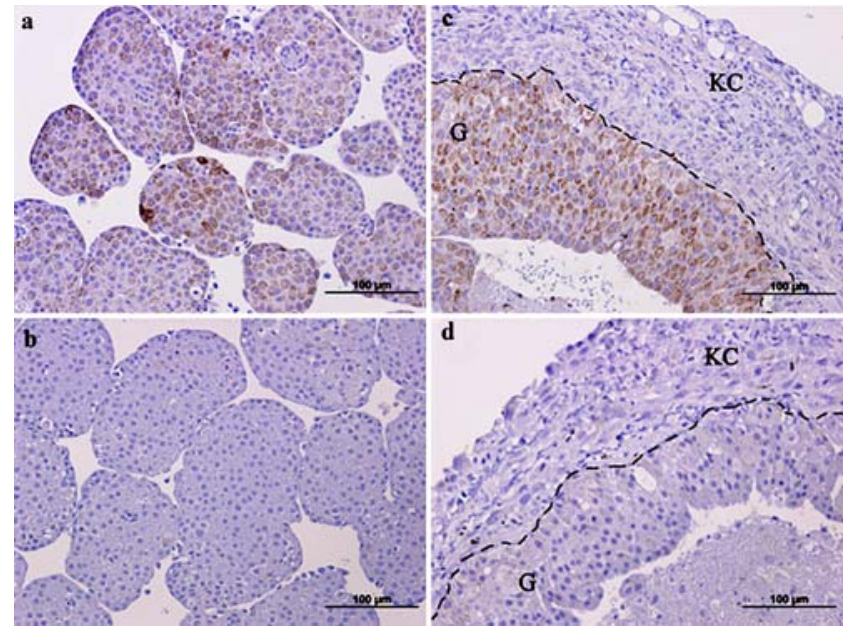

Fig. 2 IL1RN staining (brown) in Ad-IlIrn (a, c) and uninfected (b, d) islets before (a, b) and after (c, d) transplantation (day 3). $G$ indicates islet graft tissue, $K C$ indicates kidney capsule 

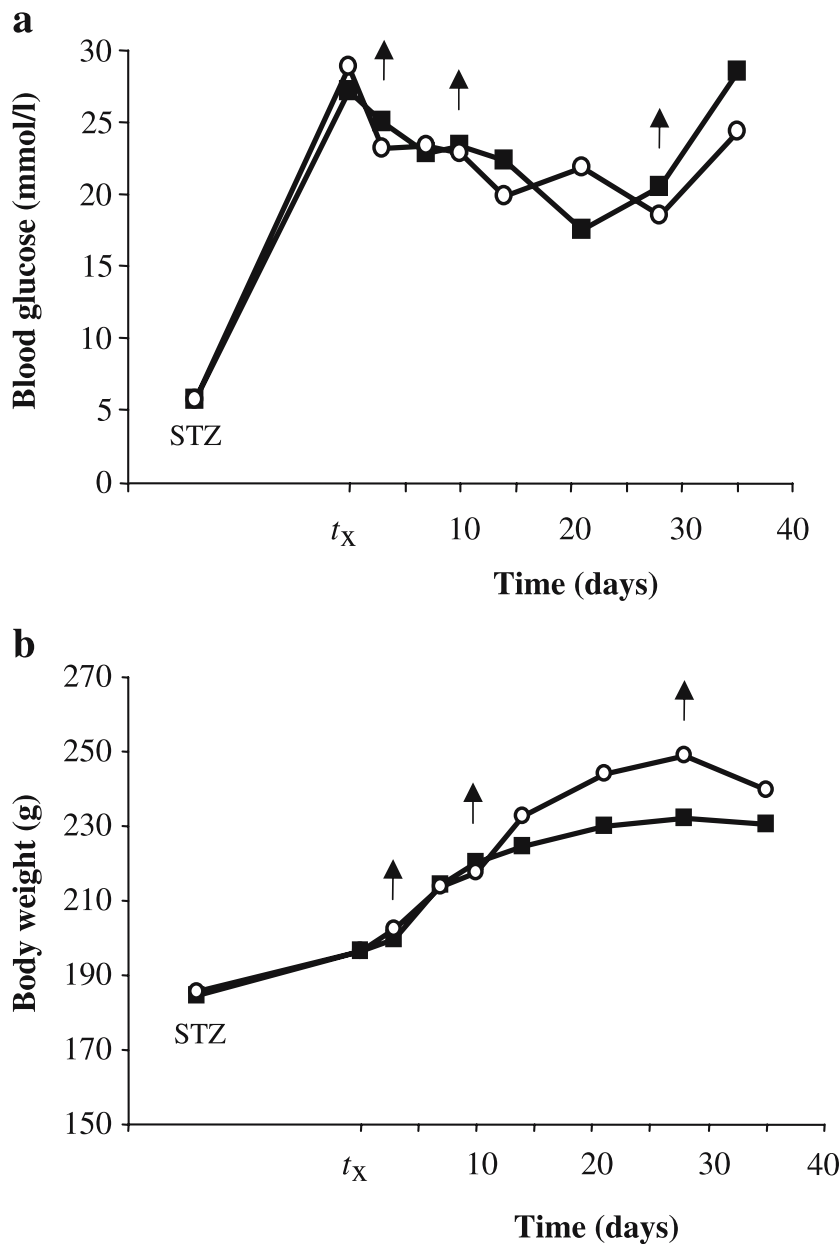

Fig. 3 Metabolic evolution after transplantation with 500 Ad-Illrn islets (open circle) or 500 uninfected islets (filled square). a Blood glucose, $\mathbf{b}$ body weight. STZ, day of STZ injection; $t_{\mathrm{x}}$, day of islet transplantation. Arrows indicate day of graft removal. Values are means $\pm \mathrm{SE}$

was used to determine specific differences between means when determined significant by ANOVA main effects analysis. A $p$ value of less than 0.05 was considered significant.

\section{Results}

Efficiency of adenoviral infection All islets and 30\% of individual islet cells produced GFP $24 \mathrm{~h}$ after infection (Fig. 1a,b). After infection the expression of the transgene was higher in peripheral cells of the islets, but was not restricted to them. After transplantation GFP expression was abundant in islet grafts, was distributed fairly homogeneously throughout the graft and colocalised primarily with insulin positive cells (Fig. 1c-e). Specific staining with IL1RN antibody showed some weakly positive cells in uninfected islets and a clear overproduction in Ad-Illrn infected islets before and after transplantation (Fig. 2).

Macrophage infiltration in syngeneic islet grafts A low number of macrophages was identified in isolated islets before transplantation, as previously described [28]. In contrast, CD-68 positive cells were abundant in islet grafts, but they were located almost exclusively outside the islet tissue around the transplanted islets. The distribution and abundance of macrophages was similar in uninfected grafts and Ad-Illrn-overproducing grafts (Electronic supplementary material [ESM] Fig. 1). No signs of rejection were found in Ad-Illrn infected grafts at any time point after transplantation.

Metabolic evolution in 500-islet grafts The evolution of blood glucose and body weight is shown in Fig. 3. All groups were comparable when injected with STZ as well as when islets were transplanted. One animal in the Ad-Illrn group achieved normoglycaemia; all others remained hyperglycaemic until the end of the study.

Beta cell replication is enhanced by ILIRN overproduction Beta cell replication was similar when beta cells were visualised using an insulin antibody or the cocktail of antibodies against the endocrine non-beta cells of the islets. Beta cell replication was significantly increased in the AdIllrn group on days 3 (insulin staining: $0.87 \pm 0.18 \%$; cocktail staining: $0.78 \pm 0.23 \%$ ), 10 (insulin staining: $1.13 \pm$ $0.16 \%$; cocktail staining: $1.15 \pm 0.16 \%$ ) and 28 (insulin staining: $0.92 \pm 0.26 \%$; cocktail staining: $1.22 \pm 0.2 \%$ ) compared with beta cell replication in normal pancreas (insulin staining: $0.37 \pm 0.08 \%$; cocktail staining: $0.24 \pm 0.04 \%$ ) (Fig. 4). In contrast, in the uninfected group, beta cell

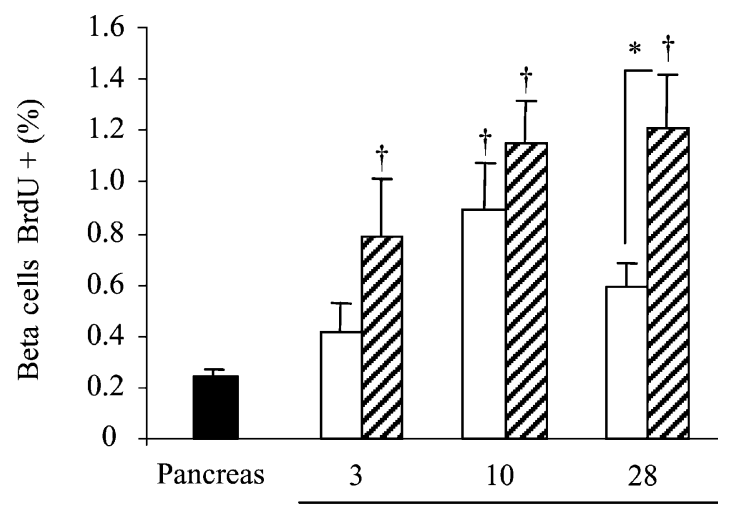

Time (days) after transplantation

Fig. 4 Beta cell replication in normal pancreas (black bar) $(n=6)$ and in transplanted islets of uninfected (empty bars) and Ad-Illrn (hatched bars) groups. Values are means \pm SE. ANOVA, $p<0.05 .{ }^{\dagger} p<0.02$ versus control pancreas, ${ }^{*} p<0.05$ between uninfected and Ad-Illrn groups on day 28 after transplantation for Fisher protected least significant difference 


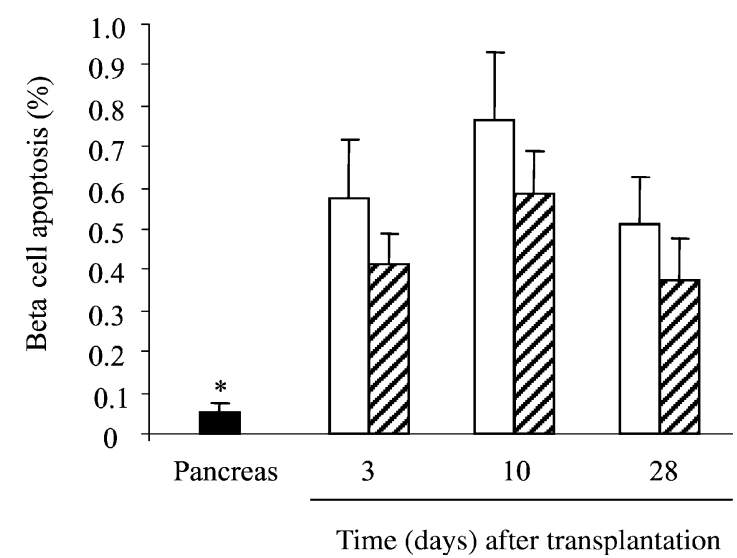

Fig. 5 Beta cell apoptosis in normal pancreas (black bar) and in transplanted islets of uninfected (empty bars) and Ad-Illrn (hatched bars) groups. Values are means \pm SE. ANOVA, $p<0.05$. $* p<0.05$ versus all other groups for Fisher protected least significant difference

replication was not increased on day 3 after transplantation (insulin staining: $0.38 \pm 0.07 \%$; cocktail staining: $0.41 \pm$ $0.11 \%$ ), and although it increased on day 10 (insulin staining: $0.72 \pm 0.07 \%$; cocktail staining: $0.89 \pm 0.18 \% ; p<0.01)$, it was reduced again on day 28 (insulin staining: $0.40 \pm 0.11 \%$; cocktail staining: $0.59 \pm 0.10 \%$ ) in agreement with previous reports of limited beta cell replication with persistent hyperglycaemia [8].

Beta cell apoptosis Beta cell apoptosis was significantly increased in transplanted islets from all groups compared to pancreas (Fig. 5). Beta cell apoptosis was $25 \%$ lower in all Ad-Illrn groups than in uninfected groups, but the difference did not reach statistical significance.

Individual beta cell size The individual cross-sectional area of beta cells in isolated islets was $116 \pm 4 \mu^{2}$, and it increased significantly in islet grafts on days 3,10 and 28

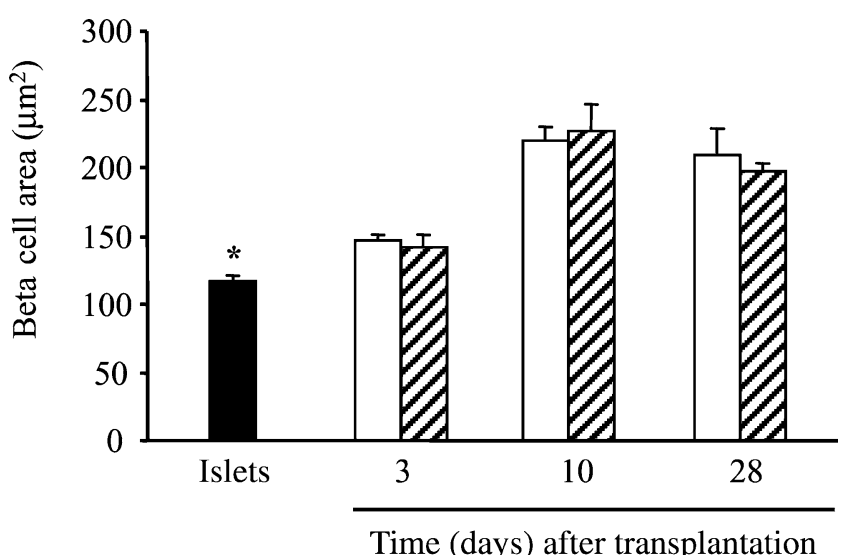

Fig. 6 Area of individual beta cells in isolated islets cultured overnight as for transplantation (black bars), and in transplanted islets of uninfected (empty bars) and Ad-Illrn (hatched bars) groups. Values are means \pm SE. ANOVA, $p<0.05 .{ }^{*} p<0.05$ versus all other groups for Fisher protected least significant difference after transplantation (Fig. 6). At all time points after transplantation, beta cell size was similar in uninfected and Ad-Illrn groups.

Beta cell mass The initially transplanted beta cell mass $(1.34 \pm 0.03 \mathrm{mg})$ was reduced in uninfected $(0.32 \pm 0.06 \mathrm{mg})$ and Ad-Illrn groups $(0.45 \pm 0.10 \mathrm{mg})(p<0.001)$ on day 3 after transplantation (Fig. 7). Although beta cell mass in AdIllrn grafts was $40 \%$ higher than in the uninfected group, the difference did not reach statistical significance. In AdIllrn islet grafts, beta cell mass was subsequently increased on days $10(1.04 \pm 0.09 \mathrm{mg} ; p<0.01)$ and $28(0.80 \pm 0.24 \mathrm{mg})$ after transplantation compared with day 3 . In contrast, in the uninfected group beta cell mass increased only on day 10 after transplantation, $(0.69 \pm 0.12 \mathrm{mg})$, dropping again on day $28(0.41 \pm 0.05 \mathrm{mg})$. The evolution of beta cell mass paralleled the evolution of beta cell replication in this group.

IL1RN overproduction improved the metabolic outcome of islet grafts To explore the effects of IL1RN overproduction on the outcome of islets grafts, STZ-diabetic rats were transplanted with 800 syngeneic islets, a borderline beta cell mass to achieve normoglycaemia.. At 14 days after islet transplantation, all animals transplanted with 800 Ad-Illrntransduced islets achieved normoglycaemia, remaining normoglycaemic until graft removal on day 28 (Fig. 8). In contrast, the group transplanted with uninfected islets remained hyperglycaemic throughout the study, and only $40 \%$ of the animals were normoglycaemic on day 14 ( $p=$ 0.03). All normoglycaemic rats developed clear hyperglycaemia after graft removal.

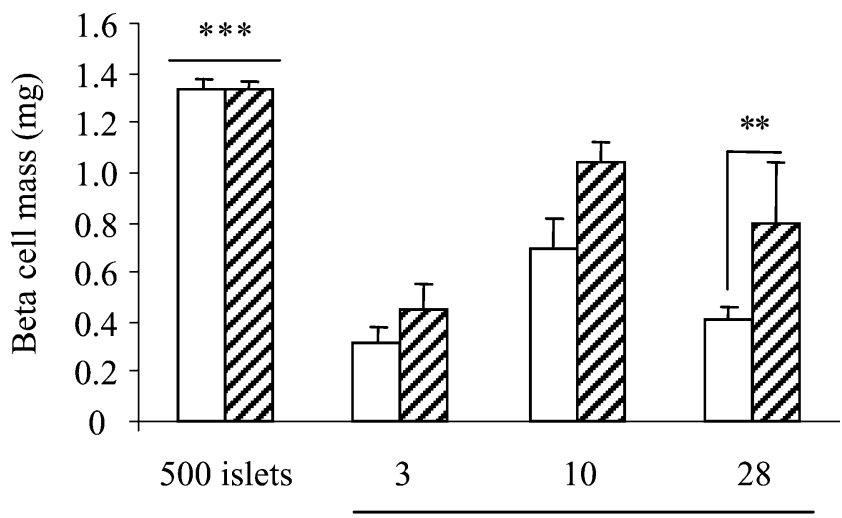

Time (days) after transplantation

Fig. 7 Beta cell mass in 500 isolated islets cultured overnight as for transplantation, and in transplanted islets of uninfected (empty bars) and Ad-Illrn (hatched bars) groups. Values are means \pm SE. ANOVA, $p<0.05 .{ }^{* *} p<0.001$ versus all other groups except Ad-Illrn on day 10 after transplantation, $* * p<0.01$ between Ad-Illrn group and uninfected group on day 28 after transplantation for Fisher protected least significant difference 


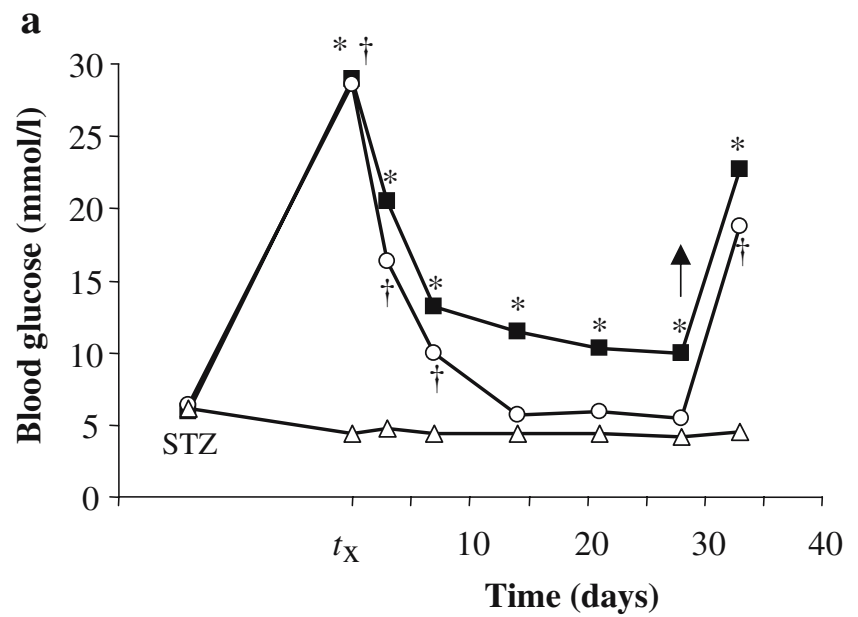

Fig. 8 Metabolic evolution of STZ-diabetic Lewis rats transplanted with 800 Ad-Il1rn islets (open circles) or with 800 uninfected islets (filled squares), and of non-diabetic non-transplanted animals (open triangles). a Blood glucose, b body weight. STZ: day of STZ injection; $t_{\mathrm{x}}$ : day of islet transplantation. Arrows indicate day of graft

\section{Discussion}

In this study, we show that the overproduction of IL1RN in syngeneically transplanted islets increased beta cell replication and mass in islet grafts, and improved the metabolic outcome. In addition, beta cell apoptosis was $25 \%$ lower in IL1RN-overproducing grafts. These beneficial effects of IL1RN overproduction on transplanted beta cells accelerated the recovery of normoglycaemia and reduced the amount of islet tissue required to consistently achieve normoglycaemia after transplantation to STZ-diabetic rats. The results provide direct evidence of the contribution of the proinflammatory IL-1 to the initial non-specific inflammation that damages transplanted islets even in the absence of rejection or autoimmune attack, and indicate that IL-1 antagonism may be a useful strategy to increase the survival of transplanted beta cells and to reduce the islet cell number required to achieve normoglycaemia after transplantation.

The initial days after transplantation are a critical period for islets. We have previously shown that on day 3 more than $60 \%$ of the transplanted beta cell mass is lost, even when islets are transplanted in optimal conditions [2]. Increased islet cell death by necrosis and apoptosis was a major contributor to this early loss of transplanted islets. The magnitude of the initial beta cell loss, previously reported in transplanted mice islets [2], was confirmed in the current experiments in a rat model. Severe reductions in grafted beta cell mass have also been suggested in studies using insulin secretion or insulin content as surrogate measurements of beta cell mass [1]. Moreover, after successful human islet allotransplantation to diabetic patients, beta cell function was only $20 \%$ of normal despite

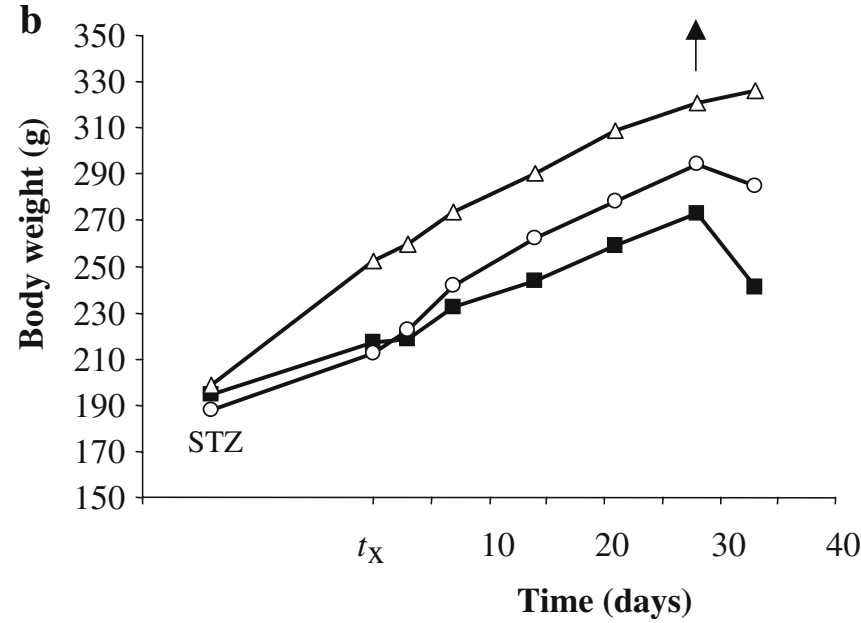

removal. Values are means \pm SE. ANOVA, $p<0.05$. ${ }^{*} p<0.05$ versus non-diabetic non-transplanted group, ${ }^{\dagger} p<0.01$ versus non-diabetic non-transplanted group for Fisher protected least significant difference PLSD

the transplantation of a high beta cell mass [29]. Thus, severe initial beta cell loss is a general process in islet transplantation. The well-known deleterious effects of IL$1 \beta$ on beta cells include the impairment of beta cell function and the induction of beta cell death $[16,17]$. In addition, IL-1 $\beta$ suppresses beta cell replication in adult rat islets in vitro [15]. Therefore, the beneficial effects that we found in beta cell replication and mass in IL1RN-overproducing transplanted islets are in agreement with the expected results of blockade of the deleterious actions of IL-1 $\beta$.

On day 3 after transplantation, beta cell replication was increased in IL1RN- overproducing grafts, but not in uninfected grafts, despite the ambient hyperglycaemia. Since it is well established that glucose increases beta cell replication $[30,31]$, the non-increased beta cell replication in uninfected islet grafts was inadequate. In contrast, beta cell replication was appropriately increased when IL-1 $\beta$ action was antagonised in IL1RN- overproducing grafts. The results indicate that IL-1 $\beta$ has an inhibitory effect on beta cell growth in early transplantation and that this effect may contribute to the initial reduction in transplanted beta cell mass.

Beta cell replication remained appropriately increased in IL1RN-overproducing islets exposed to chronic hyperglycaemia 10 and 28 days after transplantation. In contrast, beta cell replication in uninfected grafts was increased only on day 10 , but not on day 28 , despite persistent hyperglycaemia, in agreement with previous data reporting impaired beta cell replication in transplanted islets exposed to long-term hyperglycaemia $[2,6,32]$. The mechanisms of this limited beta cell replication in chronic hyperglycaemia are currently unknown. The increased beta cell replication 
in IL1RN- overproducing islets suggests that IL-1 plays a role in limiting replication in beta cells exposed to chronic hyperglycaemia, and could be in agreement with the reported, although recently questioned [33], induction of IL-1 $\beta$ production in islets exposed to chronic hyperglycaemia [34]. The substantial graft infiltration by macrophages, which we identified throughout the study and which probably occurred in response to increased beta cell death, suggests that macrophages were the major source of IL- $1 \beta$ in islet grafts.

The effects of IL-1 $\beta$ on beta cell death have been known for many years, and we expected to find a reduction in beta cell apoptosis in Ad-Illrn-infected grafts. Overproduction of IL1RN reduced beta cell apoptosis by approximately $25 \%$ in transplanted islets, but this reduction did not reach statistical significance, with beta cell apoptosis remaining increased both in IL1RN-overproducing and in uninfected transplanted islets compared with pancreatic islets of control rats. The effects of IL1RN on beta cell apoptosis may have been limited due to the multiplicity of factors that, in addition to IL-1, contribute to beta cell death in transplanted islets. Moreover, the detection of differences in apoptosis among groups may have been obscured by the short duration of the apoptotic process. Taking into account these limitations, it is interesting to note that, despite an intervention acting on a single pro-apoptotic factor only, a $25 \%$ reduction in beta cell apoptosis was achieved.

Beta cell hypertrophy was found in IL1RN-overproducing and in uninfected islet grafts, in agreement with previous observations in transplanted beta cells exposed to hyperglycaemia [2, 35]. IL-1 has no known effects on individual beta cell size, and accordingly the blockade of IL-1 action by IL1RN did not modify the size of transplanted beta cells. The similar individual cross-sectional beta cell area in IL1RN-overproducing and in uninfected islet grafts indicates indirectly that the differences found in replication and mass were due to the specific blockade of IL-1 in islets overproducing IL1RN.

Beta cell mass was dramatically reduced on day 3 after transplantation, both in uninfected and in IL1RN-overproducing islets. Although there were no statistically significant differences among groups on day 3 , beta cell mass was already $40 \%$ higher in IL1RN-overproducing grafts, possibly reflecting the higher beta cell replication and reduced apoptosis. Subsequently, increased beta cell replication and reduced apoptosis in IL1RN-overproducing grafts resulted in the restoration of initially transplanted beta cell mass on day 10 and in its preservation on day 28 , despite continuous exposure to hyperglycaemia. In contrast, beta cell mass in uninfected grafts was temporarily increased on day 10 , when beta cell replication and individual size increased, but was reduced again after 28 days of exposure to chronic hyperglycaemia due to persistently increased apoptosis and limited beta cell replication. To determine whether the positive effects of IL1RN overproduction on beta cell mass resulted in changes in metabolic control after transplantation, we performed a new group of experiments involving the transplantation of a borderline ( 800 islets) beta cell mass. In this model, the overproduction of IL1RN consistently accelerated the restoration of normoglycaemia in diabetic recipients.

We achieved the infection of all islets and of $30 \%$ of the islet cells, an infection rate which is well within the limits described in the literature [36]. It is important to note that since IL1RN is secreted and exerts a paracrine effect on neighbouring beta cells, it was active on more islet cells than just those infected by the adenovirus [20]. The development of immune intolerance against the adenovirus was not a concern in the current experiments, which focused on the initial days after transplantation, before the potential inflammatory response against the adenovirus could take place, and accordingly we found no signs of lymphocyte infiltration in IL1RN-overproducing grafts, in agreement with reports of adenoviral expression in islet grafts up to 20 weeks after infection [37].

Adenoviral vectors have been used previously to achieve transient transgene expression in islet grafts aiming to increase the survival or the growth of transplanted islets [38-44]. In islet grafts, overexpression of the antiapoptotic gene $B c l 2$ [40] and the cytoprotective gene $A 20$ (also known as Tnfaip3) [41], and overproduction of the antioxidant metallothionein [42], the mitogenic and survival factor hepatocyte growth factor $[38,43]$ or the key protein kinase B/Akt [44], have successfully improved the metabolic outcome in experimental islet transplantation. However, the effects of transgene overexpression on apoptosis, growth or beta cell mass of transplanted cells were not quantified, and the confounding effects of the different blood glucose concentrations achieved in experimental groups were not taken into account, thereby limiting overall understanding of the events that took place in the graft. Our results clearly show the importance of performing a detailed quantitative study of the graft to fully understand the mechanisms of an improved metabolic outcome. For instance, we expected that the beneficial effect of IL1RN overproduction would ensue primarily by reducing beta cell death, but the results revealed that increased beta cell replication played an important role in the beneficial effect of IL1RN overproduction.

The study of the initial damage of transplanted islets is complex due to the multiplicity of contributing factors, and the difficulties associated with the use of an in vivo model. The results of the current experiments showing that blockade of IL-1 by IL1RN improved the outcome of 
syngeneic islet grafts provide a direct indication of the role of IL-1 in early damage of transplanted islets, and support the potential therapeutic value of IL1RN in islet transplantation. Recently, treatment with IL1RN has been shown to improve beta cell function in type 2 diabetic patients [45]. Although the effects of IL- $1 \beta$ may be different in islet grafts and in type 1 and type 2 diabetes, we suggest that IL$1 \beta$ may play a dual role in beta cell mass reduction in diabetes, inducing, on the one hand beta cell death, and on the other, suppressing beta cell compensatory replication.

Acknowledgements This work was supported by a grant from the Juvenile Diabetes Research Foundation International (1-2002-687), FIS 03/0047 from the Spanish Health Ministry and Carlos III Health Institute, and a grant (RCMN C03/08) from Red de Centros de Metabolismo y Nutrición (RCMN; Metabolism and Nutrition Network of Centers). E. Estil.les and M. Montolio were partly supported by grants from the Fundació Privada Institut d'Investigació Biomèdica de Bellvitge (IDIBELL; Biomedical Research Institute of Bellvitge Foundation).

Duality of interest The authors declare that they have no duality of interest.

\section{References}

1. Davalli A, Scaglia L, Zangen D, Hollister J, Bonner-Weir S, Weir GC (1996) Vulnerability of islets in the immediate posttransplantation period: dynamic changes in structure and function. Diabetes 45:1161-1167

2. Biarnés M, Montolio M, Nacher V, Raurell M, Soler J, Montanya E (2002) Beta cell death and mass in syngeneically transplanted islets exposed to short- and long-term hyperglycaemia. Diabetes 51:66-72

3. Kaufman DB, Morel P, Field MJ, Munn SR, Sutherland DE (1990) Purified canine islet autografts. Functional outcome as influenced by islet number and implantation site. Transplantation $50: 385-391$

4. Vargas F, Vives-Pi M, Somoza N et al (1998) Endotoxin contamination may be responsible for the unexplained failure of human pancreatic islet transplantation. Transplantation 65:722-727

5. Rosenberg L, Wang R, Paraskevas S, Maysinger D (1999) Structural and functional changes resulting from islet isolation lead to islet cell death. Surgery 126:393-398

6. Kaufman DB, Rabe F, Platt JL, Stock PG, Sutherland DER (1988) On the variability of outcome after islet allotransplantation. Transplantation 45:1151-1153

7. Montaña E, Bonner-Weir S, Weir GC (1993) Beta cell mass and growth after syngeneic islet cell transplantation in normal and streptozocin diabetic C57BL/6 mice. J Clin Invest 91:780-787

8. Dionne KE, Colton CK, Yarmush ML (1993) Effect of hypoxia on insulin secretion by isolated rat and canine islets of Langerhans. Diabetes 42:12-21

9. Merino JF, Nacher V, Raurell M, Aranda O, Soler J, Montanya E (1997) Improved outcome of islet transplantation in insulintreated diabetic mice: effects on beta cell mass and function. Diabetologia 40:1004-1010

10. Ilieva A, Yuan S, Wang RN, Agapitos D, Hill DJ, Rosenberg L (1999) Pancreatic islet cell survival following islet isolation: the role of cellular interactions in the pancreas. J Endocrinol 161:357-364
11. Thomas FT, Contreras JL, Bilbao G, Ricordi C, Curiel D, Thomas JM (1999) Anoikis, extracellular matrix, and apoptosis factors in isolated islet transplantation. Surgery 126:299-304

12. Berney T, Molano RD, Cattan P et al (2001) Endotoxin-mediated delayed islet graft function is associated with increased intra-islet cytokine production and islet cell apoptosis. Transplantation $71: 125-132$

13. Ozasa T, Newton MR, Dallman MJ, Shimizu S, Gray DW, Morris PJ (1997) Cytokine gene expression in pancreatic islet grafts in the rat. Transplantation 64:1152-1159

14. Montolio M, Biarnés M, Téllez N, Escoriza J, Soler J, Montanya E. IL-1beta and iNOS expression in early syngeneic islet transplantation. J Endocrinol, in press

15. Téllez N, Montolio M, Biarnés M, Castaño E, Soler J, Montanya E (2005) Adenoviral overexpression of interleukin-1 receptor antagonist protein increases beta cell replication in rat pancreatic islets. Gene Ther 12:120-128

16. Rabinovitch A (1998) An update on cytokines in the pathogenesis of insulin dependent diabetes mellitus. Diabetes/Metab Rev 14:129-151

17. Mandrup-Poulsen T (1996) The role of interleukin-1 in the pathogenesis of insulin-dependent diabetes mellitus. Diabetologia 39:1005-1029

18. Scarim AL, Arnush M, Hill JR et al (1997) Evidence for the presence of type I IL-1 receptors on beta cells of islets of Langerhans. Biochim Biophys Acta 1361:313-320

19. Dripps DJ, Brandhuber BJ, Thompson RC, Eisenberg SP (1991) Interleukin-1 (IL-1) receptor antagonist binds to the $80-\mathrm{kDa}$ IL-1 receptor but does not initiate IL-1 signal transduction. J Biol Chem 266:10331-10336

20. Giannoukakis N, Rudert WA, Ghivizzani SC et al (1999) Adenoviral gene transfer of the interleukin-1 receptor antagonist protein to human islets prevents IL-1 $\beta$-induced beta cell impairment and activation of islet cell apoptosis in vitro. Diabetes 48:1730-1736

21. Sandberg JO, Eizirik DL, Sandler S (1997) IL-1 receptor antagonist inhibits recurrence of disease after syngenic pancreatic islet transplantation to spontaneously diabetic non-obese (NOD) mice. Clin Exp Immunol 108:314-317

22. Sandberg JO, Andersson A, Eizirik DL, Sandler S (1994) Interleukin-1 receptor antagonist prevents low dose streptozotocin induced diabetes in mice. Biochem Biophys Res Commun 202:543-548

23. Sandberg JO, Eizirik DL, Sandler S, Tracey DE, Andersson A (1993) Treatment with an interleukin-1 receptor antagonist protein prolongs mouse islet allograft survival. Diabetes 42:1845-1851

24. Bell RC, Khurana M, Ryan EA, Finegood DT (1994) Gender differences in the metabolic response to graded numbers of transplanted islets of Langerhans. Endocrinology 135:2681-2687

25. Nacher V, Raurell M, Merino JF, Aranda O, Soler J, Montana E (1996) Beta cell growth and mass are preserved in long-term syngeneic islet transplantation in streptozocin-induced diabetic Lewis rats. Diabetes 45:1541-1546

26. Maedler K, Sergeev P, Ehses JA et al (2004) Leptin modulates beta cell expression of IL-1 receptor antagonist and release of IL1beta in human islets. Proc Natl Acad Sci USA 101:8138-8143

27. Weibel ER (1979) Point counting methods. In: Weibel ER (ed) Sterological methods, vol 1. Academic, London, pp 101-161

28. Arnush M, Scarim AL, Heitmeier MR, Kelly CB, Corbett JA (1998) Potential role of resident islet macrophage activation in the initiation of autoimmune diabetes. J Immunol 160:2684-2691

29. Ryan EA, Lakey JR, Rajotte RV et al (2001) Clinical outcomes and insulin secretion after islet transplantation with the Edmonton protocol. Diabetes 50:710-719

30. Swenne I (1982) The role of glucose in the in vitro regulation of cell cycle kinetics and proliferation of fetal pancreatic beta cells. Diabetes 31:754-760 
31. Bonner-Weir S, Deery D, Leahy JL, Weir GC (1989) Compensatory growth of pancreatic beta cells in adult rats after short-term glucose infusion. Diabetes 38:49-53

32. Nacher V, Merino JF, Raurell M, Soler E, Montanya E (1998) Normoglycaemia restores beta cell replicative response to glucose in transplanted islets exposed to chronic hyperglycaemia. Diabetes 47:192-196

33. Welsh N, Cnop M, Kharroubi I et al (2005) Is there a role for locally produced interleukin- 1 in the deleterious effects of high glucose or type 2 diabetes milieu to human pancreatic islets? Diabetes 54:3238-3244

34. Maedler K, Sergeev P, Ris F et al (2002) Glucose-induced beta cell production of IL-1beta contributes to glucotoxicity in human pancreatic islets. J Clin Invest 110:851-860

35. Montana E, Bonner-Weir S, Weir GC (1994) Transplanted beta cell response to increased metabolic demand. Changes in beta cell replication and mass. J Clin Invest 93:1577-1582

36. Benhamou PY, Moriscot C, Richard MJ et al (1998) Adenovirusmediated catalase gene transfer reduces oxidant stress in human, porcine and rat pancreatic islets. Diabetologia 41:1093-1100

37. Muruve DA, Manfro RC, Strom TB, Libermann TA (1997) Ex vivo adenovirus-mediated gene delivery leads to long-term expression in pancreatic islet transplants. Transplantation 64:542-546

38. Garcia-Ocaña A, Takane KK, Reddy VT, Lopez-Talavera JC, Vasavada RC, Stewart AF (2003) Adenovirus-mediated hepatocyte growth factor expression in mouse islets improves pancreatic transplant performance and reduces beta cell death. J Biol Biochem 278:343-351
39. Contreras JL, Bilbao G, Smyth CA et al (2002) Cytoprotection of pancreatic islets before and early after transplantation using gene therapy. Kidney Int 61(Suppl 1):79-84

40. Contreras JL, Bilbao G, Smyth CA et al (2001) Gene transfer of the Bcl-2 gene confers cytoprotection to isolated adult porcine pancreatic islets exposed to xenoreactive antibodies and complement. Surgery 130:166-174

41. Grey ST, Longo C, Shukri T et al (2003) Genetic engineering of a suboptimal islet graft with A20 preserves $\beta$ cell mass and function. J Immunol 170:6250-6256

42. Li X, Chen H, Epstein PN (2004) Metallothionein protects islets from hypoxia and extends islet graft survival by scavenging most kinds of reactive oxygen species. J Biol Chem 279:765-771

43. Lopez-Talavera JC, Garcia-Ocaña A, Sipula I, Takane KK, CozarCastellano, Stewart A (2004) Hepatocyte growth factor gene therapy for pancreatic islets in diabetes: reducing the minimal islet transplant mass required in a glucocorticoid-free rat model of allogeneic portal vein islet transplant. Endocrinology 145:467474

44. Rao P, Roccisana J, Takane KK et al (2005) Gene transfer of constitutively active Akt markedly improves human islet transplant outcomes in diabetic severe combined immunodeficient mice. Diabetes 54:1664-1675

45. Donath MY, Faulenbach M, Larsen CM, Vaag A, MandrupPoulsen T (2006) Treatment with interleukin-1 receptor antagonist improves glycaemic control and $\alpha$-cell function in patients with type 2 diabetes mellitus. Diabetologia 49(Suppl 1):AO253 (Abstract) 